\title{
ABRASI GIGI DITINJAU DARI CARA MENYIKAT GIGI PADA MASYARAKAT MAJELLING KECAMATAN MARITENGAE KABUPATEN SIDENRENG RAPPANG
}

\author{
Arsyad, Andi Nur Rahmania, Muliyana
}

STIKES Muhammadiyah Sidrap

\section{ABSTRAK}

Abrasi gigi merupakan hilangnya substansi gigi melalui proses mekanisme yang abnormal, abrasi pada daerah serivikal banyak ditemukan pada orang berusia lanjut yang menyikat gigi dengan cara kurang benar. Menyikat gigi adalah suatu prosedur untuk menjaga kebersihan gigi dan mulut. Menyikatvgigi adalah membersihkan seluruh bagian gigi didalam mulut. Mengetahui Gambaran Abrasi gigi ditinjau dari cara menyikat gigi pada masyarakat Majelling kecamatan maritengae kabupaten sidenreng rappang, Untuk mengetahui cara menyikat gigi pada masyarakat Majelling kecamatan maritengae kabupaten sidenreng rappang. Untuk mengetahui kejadian Abrasi gigi di masyarakat Majelling kecamatan maritengae kabupaten sidenreng rappang. Jenis penelitian yang digunakan adalah penelitian deskriptif Kuantitatif. Hasil penelitian dari jumlah frekuesi 32 responden di Masyarakat Majelling Kecamatan Maritengae Kabupaten Sidenreng Rappang menunjukan responden terbanyak berjenis kelamin Perempuan dengan jumlah 19 responden (59\%), berumur 45-55 Tahun dengan jumlah 11 responden (34\%), Abrasi gigi terbanyak di kriteria Ringan dengan jumlah 21 responden $(66 \%)$, Cara Menyikat Gigi terbanyak kriteria Sedang dengan jumlah 19 responden ( $59 \%$ ), berjenis kelamin Perempuan mengalami abrasi gigi kriteria ringan dengan jumlah 14 responden (44\%), berusia 45-55 Tahun mengalami Abrasi Gigi kriteria Ringan dengan jumlah 9 responden $(28 \%)$, Cara Menyikat Gigi kriteria Baik dengan kriteria Abrasi Gigi ringan dengan jumlah 15 responden ( $47 \%$ ).

Kata Kunci: Abrasi, Gigi, Menyikat Gigi

\section{PENDAHULUAN}

Kesehatan gigi dan mulut yang kebersihannya terjag amerupakan bagian dari faktor yang mendukung terciptanya gigi dan mulut yang sehat, termasuk 3 jaringan periodontal. Keberhasilan pemeliharaan kesehatan gigi dan mulut dilakukan dengan tindakan menyikat gigi. Hal yang perlu diperhatikan dalam menyikat gigi adalah teknik menyikat gigi. Teknik menyikat gigi diantaranya teknik vertikal, horizontal, roll, charter, stillmen, sirkulerdan bass yang telah dikembangkan sesuai indikasi masing-masing keadaan. (Christiany, dkk, 2015)

Kesehatan gigi dan mulut merupakan bagian yang tidak dapat dipisahkan dari kesehatan tubuh secara keseluruhan. Perawatan gigi dan mulut secara keseluruhan diawali dari kebersihan gigi dan mulut pada setiap individu. (Barmo dkk, 2013)

Salah satu indikator kesehatan gigi dan mulut adalah tingkat kebersihan gigi dan mulut. Hal tersebut dapat dilihat secara klinis dari ada tidaknya depositdeposit organik. Plak gigi merupakan suatu endapan lunak yng terdiri atas kumpulan bakteri yang berkembangbiak di atas suatu matriks yang terbentuk dan merekat erat pada permukaan gigi, apabila seseorang melalaikan kebersihan gigi dan mulutnya. (Putri, dkk, 2012)

Salah satu faktor yang mempengaruhi kesehatan gigi dan mulut penduduk di Negara berkembang adalah perilaku, karena dapa tmempengaruhi status kesehatan gigi individu atau masyarakat. (Sena, 2013)

Mengingat besarnya peran perilaku terhadap derajat kesehatan gigi maka diperlukan pendekatan khusus dalam membentuk perilaku positif terhadap kesehatan gigi. Menurut penelitian Wowor (2013) yang dikutip oleh Samuel, dkk (2014) bahwa prilaku perawatan kesehatan gigi dan mulut anak perempuan lebih baik dari pada anak laki-laki. Menurut Septiyani (2012), salah satu faktor yang dapat merusak gigi adalah cara menggosok gigi yang salah. Selain dari cara menggosok gigi yang salah, hal yang menjadi faktor yang dapat merusak gigi adalah kebiasaan buruk yang biasa dilakukan.

Word health Organization (WHO) bahwa prevalensi abrasi gigi pada orang dewasa meningkat dari $3 \%$ pada usia 20 -an dan meningkat $17 \%$ pada usia 70 -an (Hanif, dkk, 2015). Prevelensi abrasi gigi di Indonesia dibagi menjadi beberapa kelompok umur. Kelompok usia 30-39 tahun yaitu 22,58\%, usia 40-49 tahun sebanyak $45,45 \%$ dan yang terbanyak pada usia 50-59 tahun sebanyak $53,33 \%$. Survei menunjukan bahwa gigi premolar adalah jenis gigi yang paling banyak mengalami abrasi yaitu $36,65 \%$ pada gigi rahang atas dan $38 \%$ pada gigi rahang bawah (Kalangie, dkk, 2016). 
Teknik menyikat gigi yang kurang tepat dapat menyebabkan tersingkapnya akar gigi akibat berpindahnya ikatan margin gingiva keposisi apical dari cementoen amejunction yang dapat mengakibatkan abrasi gigi. Abrasi yang terjadi membentuk irisan atau parit berbentuk 'V' pada akar diantara mahkota dan gingiva, mengakibatkan gigi menjadi sensitive ketika menerima rangsangan termis baik panas maupun dingin. Abrasi yang lebih lanjut juga dapat beresiko fraktur (patah) pada daerah servikal gigi. Abrasi dapat terjadi pada setiap gigi, tapi biasanya lebih banyak terjadi pada servikal bagian bukal gigi insisivus, kaninus, dan premolar di kedua rahang (Hunter dan West, 2000)

Abrasi gigi berasal dari bahasa latin "Abrader" yang artinya mengikis. Dalam arti lain abrasi gigi merupakan keausan patologis yang melibatkan jaringan kera smelalui proses mekanik yang disebabkan oleh benda asing (Hanif dkk, 2015). Cara menyikat gigi, frekuensi menyikat gigi dan tekanan yang diberikan saat menyikat gigi menjadi factor yang berhubungan dengan abrasi gigi pada seseorang. Selain itu tipe dari bulu sikat gigi, kekakuan bulu sikat gigi dan sifat abrasive pasta gigi yang digunakan juga menjadi factor dalam terjadinyaa brasi gigi. (Meshramkar, $\mathrm{dkk}, 2012)$

Penelitian ini sejalan dengan hasil penelitian Riska (2015) dengan Persamaan penelitian ini terletak pada yaitu perilaku menyikat gigi. Perbedaan penelitian ini terletak pada lokasi/tempat, sasaran/subjek penelitian. Sedangkan penelitian Patrick (2016) Persamaan penelitian ini terletak pada yaitu menyikat gigi dan abrasi gigi. Perbedaan penelitian ini terletak pada lokasi/tempat sasaran/subjek penelitian. Sehingga peneliti ingin melakukan penelitian abrasi gigi yang di tinjau dari Cara Menyikat Gigi. Berdasarkan latar belakang yang telah diuraikan maka penulis tertarik melakukan penelitian guna mengetahui "Bagaimana Gambaran Abrasi Gigi Ditinjau Dari Cara Menyikat Gigi pada Masyarakat Majelling Wattang Kecamatan Maritengae Kabupaten Sidenreng Rappang".

\section{METODE PENELITIAN}

Jenis penelitian yang digunakan adalah penelitian deskriptif kuantitatif, sebagaimana dikemukakan oleh Sugiono (2012) yaitu berlandasan pada filsafa positivism, digunakan untuk meneliti pada populasi dan sampel tertentu. Penelitian in dilakukan secara observasional yaitu suatu pengamatan yang dilakukan secara langsung oleh peneliti terhadap subjek penelitian untuk mengetahui suatu gambaran pada objek penelitian. Tiap subjek penelitian hanya diobservasi sekali saja, hal ini tidak berarti bahwa semua subjek penelitian diamati pada waktu yang sama. (Notoatmodjo, 2010)

Lokasi Penelitian ini dilakukan di Majelling Wattang Kecamatan Maritengae Kabupaten Sidenreng Rappang. Waktu penelitian ini dilaksanakan bulan 20 Juni - 20 Juli 2020.

Data yang telah diperoleh selanjutnya diolah dengan menggunakan Statistical Product and Service Solutions (SPSS) dan disajikan dalam bentuk tabel distribusi frekuensi dan presentase yang disertai penjelasan. Dalam penelitian ini, digunakan analisis data univariat merupakan analisis setiap variabel yang dinyatakan dengan sebaran frekuensi, baik secara angka-angka mutlak maupun secara persentase. Data diperoleh dengan menggunakan persentase dengan rumus distribusi frekuensi sebagai berikut:

$$
\mathrm{P}=\frac{f}{n} x 100 \%
$$

Keterangan:

$\mathrm{P}=$ Persentase yang dicari

$\mathrm{f}=$ Jumlah nilai jawaban benar dari responden

$n$ = Jumlah seluruh pertanyaan

\section{HASIL PENELITIAN}

Berdasarkan hasil pemeriksaan abrasi gigi dan hasil pemberian kuesioner tentang cara menyikat gigi pada masyarakat Majelling Wattang Kecamatan Maritenggae Kabupaten Sidenrenng Rappang, Data yang diperoleh sebagai berikut: 
Tabel 1. Karakteristik Responden Berdasarkan Jenis Kelamin

\begin{tabular}{|c|c|c|}
\hline Jenis Kelamin & Jumlah & Persentase (\%) \\
\hline Laki-laki & 13 & 41 \\
\hline Perempuan & 19 & 100 \\
\hline Jumlah & 32 & 59 \\
\hline
\end{tabular}

Berdasarkan tabel 1 menunjukan responden terbanyak berjenis kelamin perempuan dengan jumlah 19 responden (59\%).

Tabel 2. Karakteristik Responden Berdasarkan Usia

\begin{tabular}{|c|c|c|}
\hline Usia (Tahun) & Jumlah & Persentase (\%) \\
\hline $23-35$ & 4 & 13 \\
\hline $35-45$ & 10 & 31 \\
\hline $45-55$ & 11 & 34 \\
\hline $55-70$ & 7 & 22 \\
\hline Total & 32 & 100 \\
\hline
\end{tabular}

Berdasarkan tabel 2 menunjukkan responden terbanyak berumur $45-55$ tahun dengan jumlah 11 responden sebanyak (34\%).

Tabel 3. Distribusi Frekuensi Abrasi Gigi Responden

\begin{tabular}{|c|c|c|}
\hline $\begin{array}{c}\text { Usia } \\
\text { (Tahun) }\end{array}$ & Jumlah & Persentase (\%) \\
\hline $25-35$ & 4 & $13 \%$ \\
\hline $35-45$ & 10 & $31 \%$ \\
\hline $45-55$ & 11 & $34 \%$ \\
\hline $55-70$ & 7 & $22 \%$ \\
\hline Total & 32 & $100 \%$ \\
\hline
\end{tabular}

Berdasarkan Tabel 3 frekuensi abrasi gigi 21 responden (66\%).

terbanyak dikriteria ringan dengan jumlah

Tabel 4. Distribusi Cara Menyikat Gigi Responden

\begin{tabular}{|c|c|c|}
\hline Kriteria & Jumlah & Prosentase (\%) \\
\hline Baik & 11 & $34 \%$ \\
\hline Sedang & 19 & $59 \%$ \\
\hline Buruk & 2 & $7 \%$ \\
\hline Total & 32 & $100 \%$ \\
\hline
\end{tabular}

Berdasarkan Tabel 4 Menunjukkan frekuensi Cara Menyikat Gigi terbanyak yaitu dikriteria
Sedang dengan jumlah 19 responden (59

$\%)$.

Tabel 5. Tabulasi Silang Antara Jenis Kelamin dan Abrasi Gigi

\begin{tabular}{|c|c|c|c|c|c|c|c|c|}
\hline \multirow{2}{*}{ Jenis Kelamin } & \multicolumn{9}{|c|}{ Abrasi Gigi } \\
\cline { 2 - 9 } & \multicolumn{2}{|c|}{ Ringan } & \multicolumn{2}{c|}{ Sedang } & \multicolumn{2}{c|}{ Berat } & \multicolumn{2}{c|}{ Total } \\
\cline { 2 - 9 } & $\mathbf{N}$ & $\mathbf{( \% )}$ & $\mathbf{N}$ & $\mathbf{( \% )}$ & $\mathbf{N}$ & $\mathbf{( \% )}$ & $\mathbf{N}$ & $(\%)$ \\
\hline Laki-laki & 7 & $22 \%$ & 6 & $18 \%$ & - & $0 \%$ & 13 & $41 \%$ \\
\hline Perempuan & 14 & $44 \%$ & 5 & $16 \%$ & - & $0 \%$ & 19 & $59 \%$ \\
\hline Total & 21 & $66 \%$ & 11 & $34 \%$ & - & $0 \%$ & 32 & $100 \%$ \\
\hline
\end{tabular}

Berdasarkan Tabel 5 Menunjukkan responden berjenis kelamin perempuan mengalami abrasi gigi kriteria ringan dengan jumlah 14 responden (44\%). 
Tabel 6. Tabulasi Silang Antara Usia dan Abrasi Gig

\begin{tabular}{|c|c|c|c|c|c|c|c|c|}
\hline \multirow{2}{*}{$\begin{array}{c}\text { Usia } \\
\text { (Tahun) }\end{array}$} & \multicolumn{9}{|c|}{ Abrasi Gigi } \\
\cline { 2 - 9 } & \multicolumn{2}{|c|}{ Ringan } & \multicolumn{2}{c|}{ Sedang } & \multicolumn{2}{c|}{ Berat } & \multicolumn{2}{c|}{ Total } \\
\cline { 2 - 9 } & $\mathbf{n}$ & $(\%)$ & $\mathbf{N}$ & $(\%)$ & $\mathbf{n}$ & $(\%)$ & $\mathbf{N}$ & $(\%)$ \\
\hline $25-35$ & 2 & $6 \%$ & 2 & $6 \%$ & - & $0 \%$ & 4 & $12 \%$ \\
\hline $35-45$ & 8 & $25 \%$ & 2 & $6 \%$ & - & $0 \%$ & 10 & $32 \%$ \\
\hline $45-55$ & 9 & $28 \%$ & 2 & $6 \%$ & - & $0 \%$ & 11 & $34 \%$ \\
\hline $55-70$ & 2 & $6 \%$ & 5 & $16 \%$ & - & $0 \%$ & 7 & $22 \%$ \\
\hline Total & 21 & $66 \%$ & 11 & $34 \%$ & - & $0 \%$ & 32 & $100 \%$ \\
\hline
\end{tabular}

Berdasarkan Tabel 6 Menunjukkan responden berusia 45-55 tahun mengalami abrasi gigi kriteria Ringan dengan jumlah 9 responden (28\%).

Tabel 7. Tabulasi Silang Antara Cara Menyikat Gigi dan Abrasi Gigi

\begin{tabular}{|c|c|c|c|c|c|c|c|c|}
\hline \multirow{2}{*}{$\begin{array}{c}\text { Cara } \\
\text { menyikat } \\
\text { Gigi }\end{array}$} & \multicolumn{6}{|c|}{ Abrasi Gigi } \\
\cline { 2 - 10 } & \multicolumn{2}{|c|}{ Ringan } & \multicolumn{2}{|c|}{ Sedang } & \multicolumn{2}{c|}{ Berat } & \multicolumn{2}{c|}{ Total } \\
\cline { 2 - 10 } & $\mathbf{n}$ & $\mathbf{( \% )}$ & $\mathbf{n}$ & $\mathbf{( \% )}$ & $\mathbf{n}$ & $\mathbf{( \% )}$ & $\mathbf{n}$ & $\mathbf{( \% )}$ \\
\hline Baik & 15 & $47 \%$ & 7 & $22 \%$ & - & $0 \%$ & 22 & $69 \%$ \\
\hline Sedang & 5 & 16 & 3 & $9 \%$ & - & $0 \%$ & 8 & $25 \%$ \\
\hline Buruk & - & $0 \%$ & 2 & $6 \%$ & - & $0 \%$ & 2 & $6 \%$ \\
\hline Total & 20 & $63 \%$ & 12 & $37 \%$ & - & $0 \%$ & 32 & $100 \%$ \\
\hline
\end{tabular}

Berdasarkan tabel 7 menunjukkan responden memiliki cara menyikat gigi kriteria baik dengan

\section{PEMBAHASAN}

Karakteristik responden berdasarkan jenis kelamin menunjukkan bahwa responden berjenis kelamin laki-laki 13 responden $41 \%$ dan responden berjenis kelamin perempuan 19 responden 59\%. Karakteristik responden berdasarkan usia menunjukkan bahwa responden berusia 25-35 tahun dengan jumlah 4 responden $13 \%$, responden berusia 35-45 tahun dengan jumlah 10 responden $31 \%$, responden berusia 45-55 Tahun dengan jumlah 11 responden $34 \%$ dan responden berusia $55-70$ Tahun dengan jumlah 7 responden $22 \%$.

Distribusi Abrasi gigi berdasarkan tingkat keparahan atau kedalamannya, dari hasil penelitian menunjukkan sebanyak 21 responden $66 \%$ masih dalam tingkatan yang ringan, dan sebanyak 11 responden $34 \%$ Abrasi gigi dengan tingkatan yang sedang. Pada keadaan ini biasanya tidak diketahui oleh penderita karena belum menimbulkan keluhan dan kelainannya tidak begitu jelas, dan jika kebiasaan buruk dalam cara menyikat gigi terutama metode menyikat gigi yang salah terus dilakukan dengan jangka waktu yang lama akan terjadi kerusakan yang parah. Dalam keadaan ini jika tidak segera dilakukan kriteria abrasi gigi ringan dengan jumlah 15 responden (47\%).

penanggulangan, maka akan terjadi perforasi kamar pulpa dan gigi mudah patah pada bagian serviksnya.

Hasil ini didudkung distribusi frekuensi cara menyikat gigi menunjukan dengan jumlah 11 responden $34 \%$ mempunyai cara menyikat gigi sedang baik, Cara menyikat gigi sedang dengan jumlah 19 responden 59\%, dan Cara menyikat gigi buruk dengan jumlah 2 responden $7 \%$. Hasil ini menunjukan bahwa responden belum mengetahui bahwa Cara menyikat gigi yang baik dan benar dengan menggunakan metode kombinasi. Pendapat ini sesuai dengan pernyataan dari Sariningsih (2012), bahwa cara menyikat gigi yang baik dan benar yaitu: Pada bagian depan yang mengahadap bibir disikat dengan gerakan keatas kebawah (vertikal), pada semua dataran pengunyahan gigi atas dan gigi bawah disikat dengan gerakan maju mundur, pada permukaan gigi bagian depan yang menghadap lidah dan gigi depan yang menghadap langit-langit (bagian dalam) disikat dengan arah keluar dari rongga mulut dan pada permukaan gigi yang mengarah ke pipi (samping) disikat dengan gerakan memutar.

Responden juga masih banyak menggunakan alat menyikat gigi yang kurang 
tepat, rata-rata responden masih menggunakan sikat gigi dengan kepala sikat yang lebar dan besar. Menurut Soebroto (2009) dalam memilih sikat gigi yang tepat sebaiknya menggunakan sikat yang lembut, karena sikat yang keras dapat merusak enamel dan gusi, serta gunakan ukuran kepala sikat gigi yang kecil, karena ukuran sikat gigi yang kecil dapat menjangkau bagian gigi yang paling dalam sehingga dapat menghindari terbentuknya lubang-lubang gigi, penyakit gigi dan gusi.

Berdasarkan hasil tabulasi silang antara abrasi gigi dan jenis kelamin menunjukan bahwa sebagian besar responden berjenis kelamin perempuan dengan jumlah 14 responden mengalami Abrasi gigi dengan kriteria ringan $44 \%$, perempuan dengan jumlah 5 responden mengalami Abrasi gigi dengan kriteria sedang $16 \%$, dan berjenis kelamin lakilaki dengan jumlah 7 responden mengalami Abrasi gigi dengan kriteria ringan $22 \%$, laki-laki dengan jumlah 6 responden mengalami kriteria sedang $18 \%$. Abrasi gigi ini terjadi dikarenakan Masyarakat Majelling Wattang masih kurang mendapatkan pengetahuan mengenai kesehatan gigi dan mulut sehingga sebagian besar dari mereka tidak tahu cara atau metode yang tepat untuk digunakan dalam menjaga kesehatan giginya terutama mencegah terjadiya abrasi gigi.

Berdasarkan hasil tabulasi silang antara abrasi gigi dan usia menunjukan pola peningkatan abrasi gigi yang terjadi seiring dengan meningkatnya usia. Kelompok usia 45 55 tahun merupakan kelompok usia terbanyak mengalami abrasi gigi yaitu 9 responden dengan kriteria ringan $28 \%$. Hasil penelitian ini menunjukan bahwa bertambahnya usia berpengaruh pada semakin meningkatnya prevalensi abrasi gigi, mungkin dikarenakan frekuensi menyikat gigi yang sudah lebih banyak.

Berdasarkan hasil tabulasi silang antara perilaku menyilat gigi dan abrasi gigi menunjukan bahwa responden yang mempunyai perilaku menyikat gigi baik mengalami abrasi gigi ringan sebanyak 22 responden $69 \%$. Tingginya tingkat keparahan abrasi gigi pada responden selain dipengaruhi oleh perilaku menyikat gigi dengan kriteria sedang, beberapa faktor lain diantaranya karena menyikat gigi terlalu kuat sehingga menimbulkan kerusakan pada gusi dan jaringan keras gigi. Terbukti dari pengisian kuesioner yang diberikan kepada responden melakukan teknik menyikat gigi dan arah menyikat gigi yang kurang tepat. Hasil penelitian ini sesuai dengan pendapat Houwink (1993) yang menyatakan bahwa teknik menyikat gigi yang salah seperti terlalu kuat menekan dengan sikat, gerakan agresif pada waktu menyikat, terlalu lama menyikat gigi, terlalu sering menyikat gigi, sikat gigi terlalu keras, dan pasta gigi terlalu abrasif, biasanya akan ditemukan keausan pada email, dentin, dan mengakibatkan terbukanya permukaan akar gigi.

Abrasi gigi juga bisa terjadi dikarenakan penggunaan metode horizontal dalam menyikat gigi yang dilakukan secara terus menerus dengan tekanan yang berlebihan sehingga terjadi gesekan sejajar dan dapat merusak pada permukaan enamel.

\section{KESIMPULAN}

Berdasarkan hasil penelitian dan pembahasan mengenai gambaran abrasi gigi ditinjau dari cara menyikat gigi pada masyarakat majelling kecamatan maritengae kabupaten sidenreng rappang, dapat disimpulkan:

1. Masyarakat Majelling Kecamatan Maritengae Kabupaten Sidenreng Rappang menunjukan responden terbanyak berjenis kelamin Perempuan dengan jumlah 19 responden (59\%).

2. Masyarakat Majelling Kecamatan Maritengae Kabupaten Sidenreng Rappang menunjukkan responden terbanyak berumur 45-55 Tahun dengan jumlah 11 responden (34\%).

3. Masyarakat Majelling Kecamatan Maritengae Kabupaten Sidenreng Rappang menunjukkan abrasi gigi terbanyak di kriteria ringan dengan jumlah 21 responden (66\%).

4. Masyarakat Majelling Kecamatan Maritengae Kabupaten Sidenreng Rappang menunjukkan cara menyikat gigi terbanyak kriteria Sedang dengan jumlah 19 responden ( $59 \%$ ).

5. Masyarakat Majelling Kecamatan Maritengae Kabupaten Sidenreng Rappang 
menunjukkan responden berjenis kelamin perempuan mengalami abrasi gigi kriteria ringan dengan jumlah 14 responden (44 $\%)$.

6. Masyarakat Majelling Kecamatan Maritengae Kabupaten Sidenreng Rappang menunjukkan responden berusia 45-55 Tahun mengalami Abrasi Gigi kriteria Ringan dengan jumlah 9 responden (28\%).

7. Masyarakat Majelling Kecamatan Maritengae Kabupaten Sidenreng Rappang menunjukkan responden memiliki Cara Menyikat Gigi kriteria Baik dengan kriteria Abrasi Gigi ringan dengan jumlah 15 responden ( $47 \%$ ).

\section{SARAN}

Berdasarkan kesimpulan dari hasil penelitian Cara menyikat gigi dan Abrasi Gigi pada Masyarakat Majelling Kecamatan Maritengae Kabupaten Sidenreng Rappang, hal-hal yang perlu diperhatikan adalah sebagai berikut:

1. Bagi peneliti, hasil penelitian ini dapat sebagai pedoman untuk menambah ilmu dan wawasan tentang kesehatan gigi dan mulut khususnya mengenai gambaran Abrasi Gigi di tinjau dari Cara Menyikat Gigi.

2. Masyarakat Majelling Kecamatan Maritengae Kabupaten Sidenreng Rappang, Cara Menyikat Gigi sebaiknya perlu ditingkatkan lagi sehingga dapat mencegah terjadinya abrasi gigi.

3. Bagi Institusi Jurusan Kesehatan Gigi, Karya Tulis IImiah ini agar dapat menambah kepustakaan di perpustakaan Jurusan Kesehatan Gigi sehingga dapat menambah pengetahuan dan wawasan tentang pengetahuan Abrasi gigi bagi para pembaca.

4. Bagi peneliti lain, hasil penelitian ini agar dapat di jadikan tambahan wawasan ilmu mengenai Kesehatan Gigi dan Mulut khususnya tentang Cara Menyikat Gigi dan Abrasi Gigi dengan judul lain yang serupa tetapi dengan variabel yang berbeda.
Anonim. 2003. Tootbrush abrasion for your dental health. [online]. 2003 [Cited 2013 Mar 1].

Budiharto. (2010). Pengantar IImu Perilaku Kesehatan dan Pendidikan Kesehatan. Jakarta: EGC

Christiany J, Wowor P, Mintjelungan C. 2015 Pengaruh Teknik Menyikat Gigi Vertikal Terhadap Terjadinya Resesi Gingiva. Jurnal e-Gigi.Volume 3, Nomor 2.

Ghom A, Mhaske S.2008. Tootbook of ora pathology. New Delhi: Jaypee Brother Medical Publishers. p.116.

Herawati Erna, Irna Sufiawati, AyuTrisna. 2002. Prevalensi Abrasi Gigi Tetap Pada Pasien Yang Berkunjung Ke Klinik Kerja Mahasiswa Fakultas Kedokteran Gigi UNPAD. Universitas Padjadjaran Bibliografi: Pustaka IImiah.

Hunter LM. West NX. 2000. Mechanical tooth wear: the role of individual tooth brushing variables and toothpaste abrasivity. In: Addy M, Embery G, Edgar WM, Orchardson R, Editors. Tooth Wear and Sensitivity. United Kingdom (UK): Martin Dunitz. p.162.

KalangieBarten Patrick, Paulina Gunawan (2016). Prevelensi abrasi gigi di Indonesia.

Kloungploung C, Reungsok T, Songpaisan $Y$, Trichiyapon v, Chantarawati $p$. 2004. Toothbrushing behavior and dental abrasion

Litonjua A. Luis, SebastianoAndreana, Peter J. Bush \& Robert E. Cohen. 2003. 'Tooth wear: Attrition, erosion, and abrasion', Restorative Dentistry, vol. 34 , no. 6 , hh. $435-446$.

Meshramkar R.2012. Cara menyikat gigi, frekuansi menyikat gigi, dan tekanan

Natamiharja L, Hayana NB. 2009. Abrasi Gig Berdasarkan Umur, Pendidikan, Perilaku Menyikat Gigi. Dentika Dental Journal. 14 (1): $43-7$.

Periodontology and implant dentistry. 5th ed Oxford: Blackwell Publishing Ltd, 2008. P. 708-9.

Putri, Herjualianti, Nurjanah, 2012 Plak gigi.

Putri.M.H, Herijulianti.E, Nurjannah.N. 2013. IImu pencegahan Penyakit Jaringan Kerasdan Jaringan Pendukung Gigi. Jakarta. EGC.Ramadhan, Gilang A (2010). Serba-serbi Kesehatan Gigi dan Mulut. Cianjur Jakarta: Bukune.

Saxena V, Yadav N, Shanthi G, Vanka A Dubey P, Binu. 2013. Linking of multi factorial causation in abrasion of teeth among adult residents of Bhopal central india. Indian Journal od Dental Sciences.5(3):9-12

Sena. (2013). Perilaku Kesehatan Gigi dan Mulut.

Septiyani, E N A. (2012). Perilaku Menggosok Gigi Pada Anak Usia Sekolah. Karya Tulis IImiah. Ponorogo: Universitas Muhamadiyah Ponorogo.

Sulistyo, Basuki. Metode Penelitian, Jakarta: Penaku, 2010

Weijden FVD, Echeverria JJ, Sanz M, Lindhe $J$, 2008. Mechanical supragingival plaque control. In: Lindhe J, Lang NP, Karring T, editors. Clinical. 